\title{
Development of flume model of inclined capillary barrier (clay silt/CDW) in a subtropical climate scenario
}

\author{
Thays C.F. Oliveira ${ }^{1, *}$, Bianca G.S. Dezen ${ }^{1}$, and Julio C. Bizarreta-Ortega ${ }^{1}$ \\ ${ }^{1}$ Universidade Federal da Integração Latino-Americana (UNILA), Instituto Latino-Americano de Tecnologia, Infraestrutura e \\ Território (ILATIT), Foz do Iguaçu, Brasil
}

\begin{abstract}
Interest in research on capillary barrier (CB) in regions with humid climates (tropical and subtropical) is increasing. One of the main advantages of such cover type is the greater flexibility regarding the materials that could compose it. A possibility is the use of construction and demolition wastes (CDW), which would contribute to the solution of CDW destination, a problem in urban centers. Thus, the present work aimed an experimental evaluation of $\mathrm{CB}$ cover with CDW in its composition. A CB cover system was reproduced in a physical model in acrylic box, with clay soil as capillary layer and CDW as capillary block, given its granulometric and hydraulic contrast. The layers were arranged with the usual landfill slope, of 1:3, and a very heavy rain, of $90 \mathrm{~mm}$, was simulated. Three tests were performed on the flume model, in which initial CDW saturation degree $\left(\mathrm{S}_{0}\right)$ was varied in $4,5 \%, 10,3 \%$ and $17,3 \%$. Results indicate formation, indeed, of capillary barrier between the two used materials. The most efficient model was the one with lowest initial CDW $\mathrm{S}_{0}$, of $4,5 \%$. As the CWD $\mathrm{S}_{0}$ increased, time of flow permanence at materials interface decreased, indicating a CWD $\mathrm{S}_{0}$ in which such capillary barriers no longer function effectively. Regarding percolation rate, the maximum for a $90 \mathrm{~mm}$ rainfall was $2,7 \%$, which fits the landfill cover projects criteria consulted.
\end{abstract}

\section{Introduction}

The Urban Solid Waste (USW) production in Brazil is annually analyzed and quantified through the cooperation of competent agencies (e.g., ABRELPE and IBGE) along with the Brazilians city halls. Only in the year of 2018, an waste amount of 216,6 ton/day was collected in the country (collect coverage of $92 \%$ ), where the total amount is 79 millions of tons and the per capita production average is $380 \mathrm{~kg} /$ year [1].

Still according to ABRELPE [1], out of this collected quantity, $59,5 \%$ of the wastes were sent to landfills. This value, when compared to the one of 2007, represents an expressive increase $(20,9 \%)$ of USW disposition in landfills. In this context, research concerning USW landfills is extremely important, once it is necessary to assure its good functionality, due to the specificities of these constructions, that are being each time more required.

Regarding the landfills, one of their main particularities is the final covers systems. These are extremely important, especially considering their function of minimize the rainfall infiltration and its percolation into the residues mass. It is important to highlight that the refereed system directly influences in the leachate production and, ideally, they should be constituted by several layers, which are: surface layer; protection layer (that stores percolated water from the superior layer); drainage layer (that promotes the lateral flow of the percolated water); hydraulic barrier layer (which prevents the infiltration of the non-drained water); and, finally, gas collection and foundation layer ([2] and [3]).

The classic applied materials for the various final cover layers of a landfill are: low permeability soils (for hydraulic barrier layers); gravel or other inert material (for drainage and gas collection layers); and, geosynthetic materials [4].

Regarding the barrier materials, generally, compacted clay soils $\left(\mathrm{K}_{\mathrm{sat}} \leq 1 \mathrm{E}-7 \mathrm{~cm} / \mathrm{s}\right)$ are employed, however, with this technique, contraction cracks manifestation in the clay layer are common, due to wetting and drying natural processes, which can considerably affect the whole system efficiency.

As a solution for this problem, an alternative final cover system is a cover with capillary barrier effect. In this system, the contrast of the non-saturated hydraulic properties of two different granulometric overlapped layers is explored, where the superior one is formed by a thinner material (capillary layer) and the inferior one is composed by a coarser particle size material (capillary block), in order to create a barrier in the interface of these layers due to accentuated suction and hydraulic conductivity contrasts [5].

The mentioned system works in an unsaturated flow regime. When the water flows in this regime, a delay in vertical percolation occurs due to the abrupt change in the substrate pores size (interface between capillary layer and capillary block). The macropores of the capillary block offer less "attractiveness" for the water than the micropores of the material from the capillary layer itself [6].

* Corresponding author: thayscarf@gmail.com 
In addition, an especially important parameter that needs to be considered in the capillary barrier systems (CBSs) for landfills is its inclination. Kämpf \& Montenegro [7] emphasize that the inclination contribues to a more effective operation of the CBSs and Aubertin et al. [8] mention that the knowledge of this aspect of the capillary barriers is of interest, once that cover systems able to deal with a bigger water volume. This advantage of inclined CBS occurs due to what is called lateral diversion.

Concerning the barrier effect failure, Harnas et al. [9] point that in regions with more humid climate (tropical and subtropical ones, as is the case of the region in study), where the rainfall rates exceeds $1000 \mathrm{~mm}$ annually, the breaking of the barrier effect happens much more faster and the adoption of measures or different approaches to maintain the system working for a longer time is required.

One of the alternatives indicated in the literature is the use of different materials from the traditional ones for the CB layers, in general, materials available in large amounts in the landfill's proximity and that do not have an adequate destination.

One example of these materials is the Construction and Demolition Waste (CDW). Both Barros [10] and Bizarreta \& Campos [5] indicate the potential for the joint application of CDW fine fraction $(<4,8 \mathrm{~mm})$ and clay soil as an alternative technique for the final covers in landfills, exploring its non-saturated properties for capillary barrier systems. However, both works evaluated the properties of $\mathrm{CDW}$ in an isolated way, pointing for its potential of application in USW and the need of complementary studies was identified, studies that evaluate the system considering the flow that runs through the constituent layers.

An interesting and widespread technique for this type of evaluation, that is, the flow behavior through different layers, are the reduced physical models (flume models). This study approach was adopted by several authors over the years, as [7], [11], [12], [13], [14], [15], among others.

Almeida [12] and Izzo et al. [13], for example, studied a CB cover system produced with solid waste pre-treated mechanically and biologically, both carried out their researches with the flume model technique. Almeida [12] built a box of $20 \mathrm{~mm}$ glass plates, dimensions of $0,60 \mathrm{~m}$ (width) x 1,96 m (length) x 0,97 m (height); rainfall simulator system made with PVC pipes with drippers; and, three drain points (PVC pipes wrapped in geotextil membrane and gravel), two in each layer foot of the CBS and one for runoff. Izzo et al. [13], on the other hand, built a $0,6 \mathrm{~m} \times 1,80 \mathrm{~m} \times 0,44 \mathrm{~m}$ acrylic box; for the rainfall simulator system, sprinklers were employed; and the drains were also made of PVC pipes. Zhan et al. [14] analysed a three-layer inclined capillary barrier (with classical materials, silt, sand and gravel, respectively from top to bottom). Their physical model was built with acrilic plates, dimensions of $1,0 \mathrm{~m} \times 2,0 \mathrm{~m} \times 1,2 \mathrm{~m}$, rainfall simulator with sprinklers and drains of PVC pipe wrapped in a wire mesh.

Therefore, this works aims to develop a reduced physical model in order to study the CB effect in inclined cover systems in humid climate region, specifically, a subtropical climate, as the one of Foz do Iguaçu-PR (city where the present research was developed). The materials applied in the study were the CDW (as cappilary block) and the soil available in the region (clay silt, as capillary layer).

An interesting point of this work is the use of CDW, once large volumes of this materials are constantly being produced and solutions for the reincorporation of this material in the construction industry are required (as use in paving, concretes and landfills components). In addition, in the city where the research was developed, the CDW is not diposed in inert landfills as recommend by environmental regulations, but in the same landfill of the city USW, which represents a serious problem to the city USW management that need to be solved.

\section{Material and methods}

The present work was divided in two main stages, where the first was the collect of the materials that were used in the research (soil and $\mathrm{CDW}$ ) and its physical and hydraulic characterization, and the second, the development of the reduced physical model (flume model) for the inclined capillary barrier simulation in subtropical climate conditions (climate of the region of study).

\subsection{Materials characterization}

The used materials were the residual soil from the region (applied as capillary layer in the flume model) and CDW (applied as capillary block). Both materials were collected in the Urban Solid Waste Landfill (USWL) in Foz do Iguaçu. The collected soil is available around the USWL, which is the same that is used in the procedures of daily and final covers. The CDW is collected from all places of the city and directed to the USWL, once the city does not have a specific destination for this type of material. These residues are disposed in piles without separation between coarse and fine fractions. For this reason, the sifting in loco of this material was needed, in the mesh \#4 $(4,8 \mathrm{~mm})$. After collect process, all the material was stored with hygroscopic humidity in plastic baskets or in fabric bags, in a climatized chamber with temperature varying between 20 to $24^{\circ} \mathrm{C}$, in order to use it in the following steps.

The characterization of both materials was made according to the current Brazilian standards and/or according to literature recommendations, as follows:

- $\quad$ Specific mass: NBR 16605 [16];

- Granulometry: NBR 7181 [17];

- Compaction curve: NBR 7182 [18];

- $\quad$ Saturated permeability coefficient: NBR 14545 [19] for soil and NBR 13292 [20] for CDW;

- Soil-water characteristic curve: Villar [21] and Bizarreta [22].

Samples separation and preparing processes were executed according to NBR 6457 [23], except for the soilwater characteristic curve test, where the samples were extracted from the flume model (after the capillary barrier simulation test), which will be detailed in the following section. 


\subsection{Flume model}

The inclined flume model was developed aiming the simulation of a capillary barrier made of soil and CDW under conditions of intense rainfall, which frequently occurs in subtropical regions. The study of the capillary barrier behavior through flume models is an approach that had been being used by many authors ([7], [11]; [12]; [13]; [14]; [15]), although it is not standardized. It is based in the execution of the layers of a CBS in a box or in specific apparatus, where rainfall events are simulated for measurements of percolated water volume over time. Such percolated water measurements are made in the different system layers through drains (and in some cases through sensors), where these are inserted in different positions of the box/apparatus.

In the present work, the flume model was designed/ developed with 0,3 (width) $\times 1,0 \mathrm{~m}$ (length) $\times 0,7 \mathrm{~m}$ (height), with lateral faces in $10 \mathrm{~mm}$ acrylic plaques and bottom in a $12 \mathrm{~mm}$ wooden plate reinforced with $30 \mathrm{~mm}$ iron bars. The design can be seen in Figure 1 .

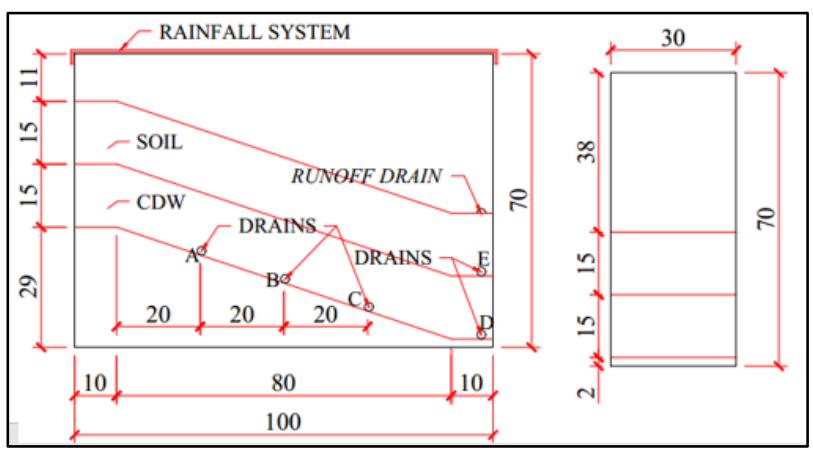

Fig. 1. Flume model design.

The acrylic plaques/wood plate were fixed together by "U" aluminum profiles and by elastic adhesive based in silyl modified (SM) polymer. Then, the wooden plate was impermeabilized with asphalt emulsion and impermeabilization tests were made, by filling the box with water and verifying the possible existing leaks.

After the tightness verification of the box, this one was filled with sand in order to "mold" the inclination 1:3 $(\mathrm{H}: \mathrm{V}), 18^{\circ}$ approximately, value that is usual for landfills slopes. Above the sand, another wooden plate was installed to isolate this material, and the contact between the wood and the acrylic was sealed with silicone. In this step, another impermeabilization test was carried out. The initial box assembly can be seen in Figure 2 .

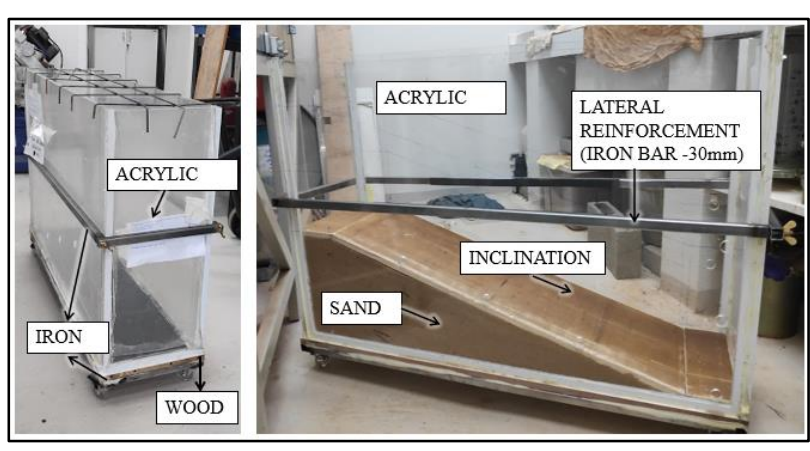

Fig. 2. Flume model assembly.

Finally, a lateral reinforcement for the box was produced, to avoid its arching due to the material filling and compaction processes. This reinforcement was made with $30 \mathrm{~mm}$ iron bars, the same ones used in the box bottom (under the wooden plate).

\subsubsection{Drains}

For the flume model of the present work, six (06) drains were used for system monitoring of runoff and percolated water volumes: three (03) for the vertical percolation measurement (Figure 1, drains A, B and C); two (02) for the horizontal percolation, in the layer's foot, capillary (soil) and block (CDW) (Figure 1, drains D and E); and, one (01) for runoff. The drains were made with $20 \mathrm{~mm}$ PVC pipes perforated along the water collect length and, specifically for the runoff drain, an opening along its whole length was made, due to the greater water volume that was going to be collected (Figure 3).

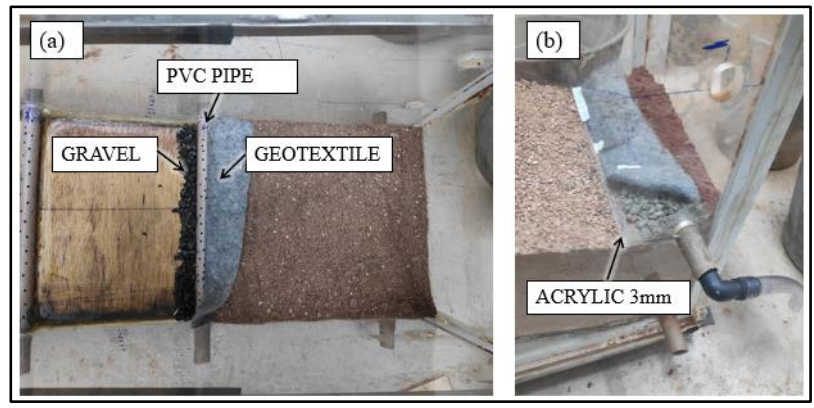

Fig. 3. Drains. (a) Drain C. (b) Drain E.

For the installation of the drains in the box, holes in the acrylic plaques were made previously to its fixing with the wooden plate. Also, PVC pipes passed through the two box faces, letting the drain with an inclination to the side of water collect.

During the experimental molding, the drains were wrapped in a gravel layer (draining material) under a geotextile layer (filtering material), as showed in Figure 3.a. The drains A, B and C (collect of the vertical percolation in the CDW layer) were tested before the material was put in the box. For the superior drains (bottom capillary layer and runoff), an impermeable material was used under the drain $(3 \mathrm{~mm}$ acrylic plate, Figure 3.b) in order to avoid the flow of the accumulated 
water in these points into the lowers layers without the appropriated collect.

\subsubsection{Rainfall simulator}

Regarding the rainfall simulation system, a $1 / 4$ " flexible hose with small holes was used, fixed in a steel welded grid, aiming a better directing of the rain to the barrier (and not to the contact soil-acrylic, as it may occur in the sprinkler cases) (Figure 4).

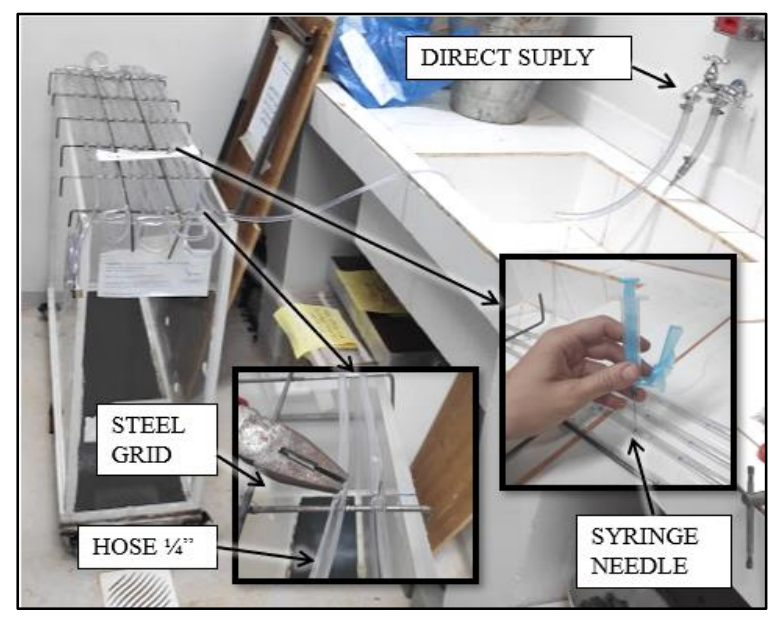

Fig. 4. Rainfall simulator system.

The rainfall simulator system was designed to cover $85 \%$ of the initial stretch of the flume model, because the rainfall occurrence in $100 \%$ of the box area could camouflage the runoff and the percolation results. The hose holes were made with a syringe needle (small diameter), in order to avoid a torrential rain.

A volume of $90 \mathrm{~mm}$ rain was fixed, based in the 20 year rainfall historical data survey (jan/1998 a dez/2018) of Foz do Iguaçu - PR, compiled from the Paraná Meteorological System-SIMEPAR [24]. This volume represents strong rainfalls (above $50 \mathrm{~mm}$ ) according to Moreira [25] classification, which corresponds to 5,9\% of all the rainfall events within the 20 -year range analyzed. Within this $5,9 \%$ of very heavy rain events, rainfalls above $90 \mathrm{~mm}$ represents less than $1 \%$ of the rainfall events, therefore, this was the maximum value (limit) fixed for the tests in the present work.

\subsubsection{Flume model test methodology}

For molding the test/experiment the layers were compacted with a laboratory-made tool, aiming a compaction degree (CD) of $80 \%$ for the soil. This value was also used in other works such as in Costa et al. [26] and Maciel \& Jucá [27] for clay soils in landfills. The CDW was compacted without compact energy control, however, the initial saturation degree $\left(\mathrm{S}_{0}\right)$ was varied, in order to verify the influence of this parameter in the results of the flume model percolation. After CB compaction materials, the soil received a thin gravel layer to avoid its erosion due to the rain. Altogether, three tests were performed, as shows Table 1.
Table 1. Tests description. (w: moisture content; irain: rain intensity; volT.: total volume)

\begin{tabular}{c|c|c|c|c}
\hline Test & $\begin{array}{c}\text { CDW } \\
\mathbf{S}_{\mathbf{0}}(\mathbf{\%})\end{array}$ & $\begin{array}{c}\text { CDW } \\
\mathbf{w}(\mathbf{\%})\end{array}$ & $\begin{array}{c}\mathbf{i}_{\text {rain }} \\
(\mathbf{m m} / \mathbf{h})\end{array}$ & $\begin{array}{c}\text { Rain vol } \\
\mathbf{( m m})\end{array}$ \\
\hline E1 & 4,5 & $1,5^{*}$ & 91,8 & 210,7 \\
E2 & 10,3 & 3,5 & 101,5 & 208,0 \\
E3 & 17,3 & 5,9 & 91,1 & 121,4 \\
\hline
\end{tabular}

*hygroscopic moisture

Despite initial definition of a $90 \mathrm{~mm}$ rain, in the cases where no percolated volume was measured by the drains, the rainfall phenomenon was extended until the drain activation. For this reason, Table 1 shows a real value of rain volume, which corresponds to the "Rain vol ${ }_{\mathrm{T}}$ " column.

The real value of rain volume of the test is bigger than the idealized conditions and it is a little bit far away from the reality presented in the historical data, but, in the other hand, the system was subjected to very extreme conditions. NG et al. [15] also simulated a torrential rainfall event, in which intensity was $73,8 \mathrm{~mm} / \mathrm{h}$ during $4 \mathrm{~h}$, totalizing an amount of 295,2 $\mathrm{mm}$ of rain.

While the test was being executed, the periods of water percolation in the soil and CDW layers were registered, as well as the permanency period in the $\mathrm{CB}$ and the operation beginning period of each drain. Also, volume measurements of the drain collect were performed every $10 \mathrm{~min}$ in the experiment for the initial 2 hours. Posteriorly, the collect volume of each drain after $4 \mathrm{~h}, 8 \mathrm{~h}$ and $24 \mathrm{~h}$ were measured, regarding the initial beginning time test and it could be verified that only the drain D (capillary block foot) operated after the rainfall event ended.

\section{Results and discussion}

\subsection{Materials characterization}

The material granulometric curves and the Atterberg limits indicate that the soil that was used in the present work is a low plasticity sandy clay, CL (according to the USCS classification). The CDW can be classified as a silty sand, SM. These results are shown in Figure 5.

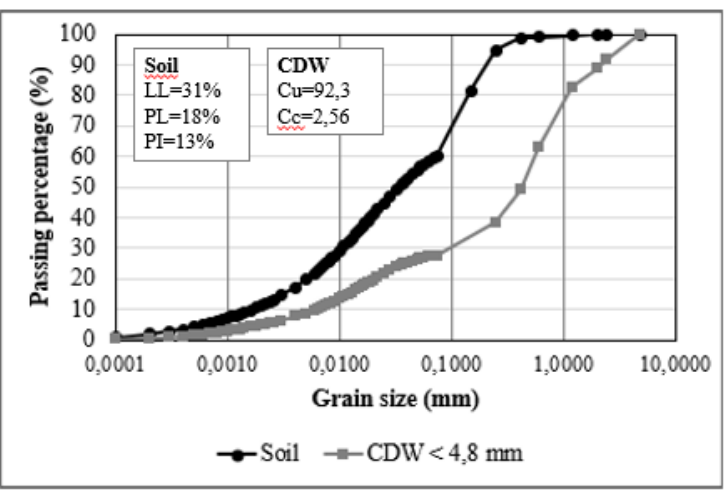

Fig. 5. Granulometric curves of soil and CDW. (LL: liquidity limit; PL: plasticity limit; PI: plasticity index; $\mathrm{Cu}$ : uniformity coefficient; Cc: curvature coefficient). 
Through this test, a granulometric contrast between both materials was indeed observed, which points to the possible use of both materials for a $\mathrm{CB}$ composition, in accordance with Barros [10] and Bizarreta \& Campos [5]. Nevertheless, the CDW also presented a considerable fine content (particles passing in mesh \#200), which could partially damage the capillary barrier effect.

The compaction results can be observed in Figure 6, for situations with and without material reuse. Results are consistent with other results presented by Das \& Sobhan [28] for the same material type (considering the USCS classification). Also, there was almost no change in the CWD curve due to the material reuse, however, the possibility that the compaction could change CDW grains granulometric distribution (due to its break) is not discarded and complementary analysis (granulometry after compaction) would be required to verify this hypothesis.

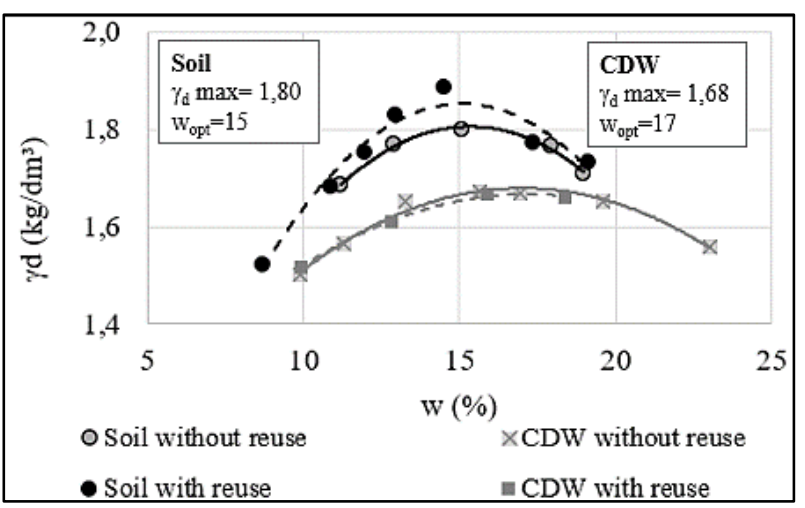

Fig. 6. Compaction curves of soil and CDW. (w: moisture content; $w_{\mathrm{opt}}$ : optimum moisture content; $\gamma_{\mathrm{d}}$ max: maximum dry density).

Regarding the grains specific mass (Gs) and the saturated permeability coefficient (ksat), the results can be observed in Table 2. Permeability results evidence the difficulty in reaching low permeabilities for a soil with an $80 \%$ compaction degree, characteristic that is required for its use in monolithic covers. High CDW permeability was also observed.

Table 2. Gs and ksat results.

\begin{tabular}{c|c|c}
\hline Material & Gs & $\begin{array}{c}\mathbf{k}_{\text {sat_20 }}{ }^{\circ} \mathbf{C} \\
(\mathbf{c m} / \mathbf{s})\end{array}$ \\
\hline Soil & 2,71 & $1,64 \mathrm{E}-04$ \\
CDW & 2,70 & $1,62 \mathrm{E}-02$ \\
\hline
\end{tabular}

Finally, regarding the soil-water characteristic curve (Figure 7), we can note that the soil has a bigger water retention capacity than the CWD, as expected, evidencing the suction materials contrast. This indicates the potential formation of a capillary barrier between both materials, with their associated use [29].

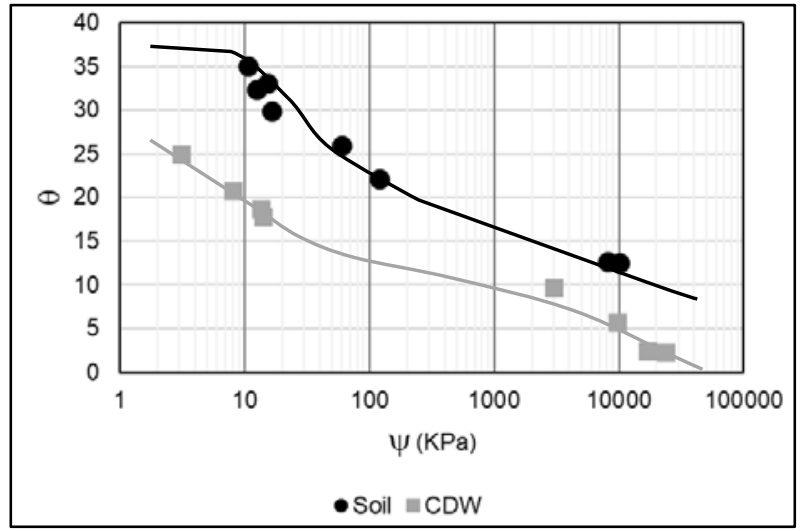

Fig. 7. Soil-Water Characteristic Curve of soil and CDW. ( $\theta$ : volumetric moisture content; $\psi$ : suction).

Despite that, the CWD also presents a considerable water retention capacity, i.e., the curve is slightly different from the sand ones, which was also observed by Bizarreta \& Campos [5]. Possibly, this occurs due to the CDW particles microposority, which would demand more detailed studies about this aspect for posterior confirmation.

In general, comparing the obtained results of this work with others of the literature ([5] and [30]), a huge variability in CDW characteristics was identified, which can be a limiting factor to this work proposition or to others works that aim the reuse/recycling of these wastes.

\subsection{Flume model}

The flume model tests indicated indeed the occurrence of the capillary barrier effect between the soil and CDW. Through these tests, percolation velocities, permanency period of the flow in the materials interface ("CB period") and the collected volume water by drains were measured, as the scheme shown in Figure 8.

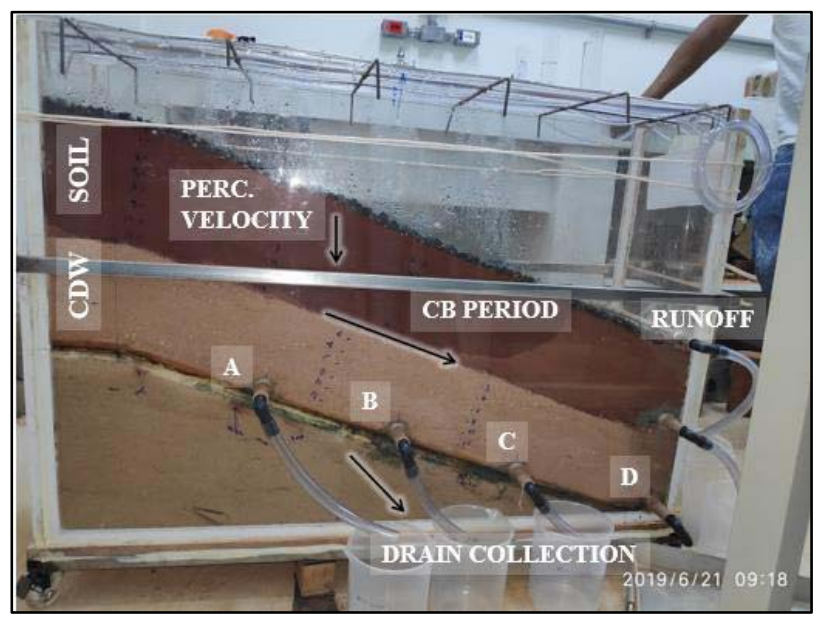

Fig. 8. Capillary barrier test.

In Table 3, the permanency time of the flow in the materials interface before the water advance to the capillary block (CDW), column "BC (s)", can be observed. Also, percolation velocity results are presented, 
as well as some parameters that were verified a posteriori through the extraction of undisturbed samples (dry density, $\gamma_{\mathrm{d}}$, its respective compaction degree, CD, and field capacity, $\left.\mathrm{w}_{\text {field }}\right)$.

Table 3. Flume model results.

\begin{tabular}{|c|c|c|c|c|}
\hline \multirow{2}{*}{ Test-S $\mathbf{S}_{0}$} & \multicolumn{2}{|c|}{ Perc. vel. $(\mathrm{cm} / \mathrm{s})$} & \multirow[t]{2}{*}{ BC (s) } & \multirow{2}{*}{$\begin{array}{c}\text { Soil CD } \\
(\%)\end{array}$} \\
\hline & Soil & CDW & & \\
\hline E1-4,5\% & $9,29 \mathrm{E}-03$ & $2,86 \mathrm{E}-03$ & 178 & 83,8 \\
\hline E2-10,3\% & $1,43 \mathrm{E}-02$ & $2,87 \mathrm{E}-03$ & 179 & 82,2 \\
\hline E3-17,3\% & $1,38 \mathrm{E}-02$ & 7,24E-03 & 95 & 81,7 \\
\hline \multicolumn{5}{|c|}{ (continuation...) } \\
\hline \multirow{2}{*}{ Test-S } & \multicolumn{2}{|c|}{$\gamma_{\mathrm{d}}\left(\mathrm{kg} / \mathrm{dm}^{3}\right)$} & \multicolumn{2}{|c|}{ Wfield $(\%)$} \\
\hline & Soil & CDW & Soil & CDW \\
\hline E1-4,5\% & 1,51 & 1,40 & 23,9 & 15,7 \\
\hline E2-10,3\% & 1,48 & 1,38 & 22,5 & 17,0 \\
\hline E3-17,3\% & 1,47 & 1,38 & 23,5 & 16,3 \\
\hline
\end{tabular}

The percolation velocities in the soil resulted in similar values and the predicted $80 \%$ CD was confirmed. Regarding the CDW, it is observed that as the initial saturation degree increased, the percolation velocities also increased, which, as consequence, shortens the flow arrival period at the foot layer (this would represent the wastes in real conditions - a landfill). The same observation is valid for the permanency time of the flow in the $\mathrm{CB}$ (bigger $\mathrm{S}_{0}$, lower time), which may indicate the existence of a point, i.e., a CDW saturation value from where the $\mathrm{CB}$ effect between the materials stop being effective.

In addition, lateral flow measurements of soil layer were taken, which resulted in average $2,5 \mathrm{E}-02 \mathrm{~cm} / \mathrm{s}$ and throughout the test, it could be noted that the runoff drain just started operating after the arriving of the laterally flow under the drain. Also, during flow permanency in the materials interface, the advance of lateral flow in the clay layer went on.

Through samples taken from the flume model $a$ posteriori, materials field capacity were estimated which resulted in $23,3 \%(\theta c c \approx 35 \%)$ for the soil and $16,3 \%$ $(\theta \mathrm{cc} \approx 23 \%)$ for the CDW. Both presented a good water storage capacity, which corroborates with materials soilwater characteristic curve. A correspondent rain volume value was calculated, this volume would be retained in the flume model layers (considering the adopted thickness in the present work and the initial materials moisture). An average value of $32,8 \mathrm{~mm}$ was obtained for the soil and $28,3 \mathrm{~mm}, 27,0 \mathrm{~mm}$ and $20,8 \mathrm{~mm}$, for the CDW with $\mathrm{S}_{0}$ of $4,5 \%, 10,3 \%$ and $17,3 \%$, respectively. This is an interesting result once the $\mathrm{CB}$ system is capable of retaining by itself the rainfall events that are bigger than $50 \mathrm{~mm}$, for the analyzed conditions. In a practical point of view, the materials are close to the atmosphere and, therefore, they would be susceptible to other moisture conditions due to possible successive rainfall occurrence and its evaporation (moistening and drying cycles), what would give different results.

Regarding percolation monitoring through the drains, the biggest rainfall amount was collected by the runoff drain, possibly because of the high rain intensity, which caused the water accumulation on the surface, with consequent runoff. The second drain with the higher collected water volumes was the D one (capillary block foot, $\mathrm{CDW}$ ), which corresponds to the lower point of the system. These results can be observed in better details in Table 4.

Table 4. Drain collection results. (R: runoff drain).

\begin{tabular}{c|c|c|c|c|c|c|c}
\hline \multirow{2}{*}{ Test } & \multirow{2}{*}{$\begin{array}{c}\text { Rain } \\
\text { (mm) }\end{array}$} & \multicolumn{6}{|c}{ Drain collection (\%)* } \\
\cline { 3 - 8 } & & $\mathbf{R}$ & $\mathbf{A}$ & $\mathbf{B}$ & $\mathbf{C}$ & $\mathbf{D}$ & $\mathbf{E}$ \\
\hline E1 & 210,7 & 83,8 & --- & 0,9 & 0,3 & 15,0 & --- \\
E2 & 208,0 & 90,9 & --- & 0,3 & --- & 8,8 & --- \\
E3 & 121,4 & 44,2 & 9,1 & 7,0 & 10,7 & 28,4 & 0,6 \\
\hline
\end{tabular}

*Percentage regarding the total collected amount (drain sum). Part of the water was retained in the system itself.

We can observe that the E3 test $\left(\mathrm{S}_{0}=17,3 \%\right)$ presents a different behavior from the others, with certain balance between the drain readings. A possible explanation for this fact is that water percolated faster in this test (as previously discussed), due to the greater initial saturation degree of CDW when compared to E1 and E2 tests. In case of total CDW saturation, water volumes collected by drains would be even greater, i.e., system percolation rates depend on initial saturation of capillary block (greater moisture, lower permeability contrast between the materials). Besides that, it (E3) was the only test where the drains presented an adequate operation.

The different rain volumes between the tests (due to the limitations in controlling the rain simulator, which depended on the distribution system flow rate) made the direct comparison of results unfeasible. For this reason, the collect volumes in each drain were converted to rains of $90 \mathrm{~mm}$ (initial proposed value), considering a linear relation. Thus, the contribution percentage of the drains (A, B, C and D, which represent the volume that would enter the residues mass) were obtained, regarding a $90 \mathrm{~mm}$ rainfall event. For E1 and E2 tests, the contribution is zero and for the E3 test, the value was $2,7 \%$. These results are positive, once they demonstrate that extremely rare events would be necessary for the flow to cross all the $\mathrm{CB}$ system proposed, given the conditions tested in the present work. Other authors as Krisdani et al. [31] and NG et al. [15] that also used cohesive soils in the $\mathrm{CB}$ obtained similar results.

There is not a consensus or standard that indicates an acceptable range of values for the percentage of rainfall that percolates into the residues mass [2], however, Hauser [32] suggests a maximum value of 3\% (annually). Hence, results of this work are satisfactory. Other authors as Silva [33] and Oliveira \& Braga [34] point that in Brazil, this percentage reaches values up to $50 \%$.

The rainfall percentage parameter that percolates into the residues mass is one of biggest interest for the final cover landfill designs, because from this value it is possible to determinate the produced leachate quantity (formulations in [35]), where the lower the values the better, what could assist in the contingency of soil and hydraulic bodies contamination in landfills surroundings, 
as well as economy in drainage systems and/or leachate treatment or recirculation systems.

\subsubsection{Flume model limitations}

The approach of this work consists in a non-standardized experimental methodology and, therefore, during the tests several limitations were identified, limitations that can be improved for future researches involving flume models.

The first limitation refers to the wooden plate of box bottom, the one over the sand, which molded the system inclination: this element impermeabilization failed, which caused both water absorption and its expansion, resulting in leaks under the CB system layers. For future tests, the wood could be replaced by a PVC plate or a similar material, that would not absorb water.

Another limitation was the adequate control of rainfall simulator flow rate, once the initial estimated rainfall values did not match the values that were in fact supplied to the system. For future tests a possibility would be the use of reservoirs with a pre-defined volume and pumps, just as suggested by Almeida [12]. Other alternative would be the use of a rotameter (flow meter) linked to the supply system tap, for a constant control of the tap and, therefore, of the rainfall flow rate.

Finally, the biggest limitation of this work was probably the inadequate drain operation of some drains (for the extreme rainfall conditions, when water flow reaches the capillary block foot). One explanation for this problem is the low water level (movements in unsaturated conditions) and the non-saturation condition of the geotextile, which could form a CB itself above the drain. For future researches, a suggestion would be to perform an opening along the whole drain length (such as the one made for the runoff drain), and, added to that, its filling with gravel, in order to make easier the water entry into the element.

\section{Conclusions}

The results of this work indicate that the studied materials (soil from the region, CL-USCS, and the fine CDW fraction, SM) are compatible for the associated application in capillary barrier systems, with the use of the soil as the capillary layer and of the CDW as the capillary block. Through the characterization tests the granulometric contrasts between the materials as well as the water retention capacity (suction) contrasts could be noted. Regarding the soil-water characteristic curve, it was observed that the CDW has a considerable retention capacity (bigger than the natural materials classified as SM, which possibly occurs due to the particles porosity that form the CDW (for example, ceramic/bricks or cement residues).

The flume model tests indicated that there is an initial $\mathrm{CDW}$ saturation value from where the $\mathrm{CB}$ mechanism between the materials is no longer effective (in the case of this work, this value would be between $10,3 \%$ and $17,3 \%$ ). In other words, CB system operation depends on initial saturation degree of capillary block. Another important observation is that after $\mathrm{CB}$ break, vertical percolation in capillary block (CDW) is even slower than in capillary layer (soil). These conditions favor the percolation minimization of water into the residues mass in this type of cover system.

Despite the research limitations, that came along with the experimental methodology that was applied, positive results have been reached. The presented proposal is a subject of interest because in addition to replacing a substantial amount of natural material used in the final landfills covers (the soil), it employs other material that is widely available in urban centers (CDW), whose final disposal is complex. Also, the amounts of generated CDW in the cities in last years have been growing and this material requires solutions to be reincorporated in the industrial/construction sector.

Lastly, more realistic studies, considering the water balance (evapotranspiration) in these type of cover systems would be interesting to a better understanding and evaluation of this work proposal.

\section{References}

1. ABRELPE. (2019). Panorama dos residuos sólidos no Brasil 2019. Available in: $<$ https://abrelpe.org.br/download-panorama-20182019/>. Acess: 28 sep. 2020.

2. R. M. Koerner \& D.E. Daniel. (1997). Final covers for solid waste landfills and abandoned dumps. ASCE.

3. D. KovačIć. (1994). Materials for the final cover of sanitary landfills. Rudarsko-geološko-naftni zbornik 6, 11-15.

4. F. G. Simon \& W. W. Müller. (2004). Standard and alternative landfill capping design in Germany. Environmental Science \& Policy 7, 277-290. doi:10.1016/j.envsci.2004.04.002

5. J. O. Bizarreta \& T. P. Campos. (2017). Caracterização geotécnica de um RCD e uma argila visando sua utilização como barreira capilar. In: E. L. Cardozo. Geologia ambiental: Tecnologias para o desenvolvimento sustentável - vol. 2, 19-33. Ponta Grossa: Atena.

6. R. R. Weil \& N. C. Brady. (2017). The Nature and Property of Soils. 15. ed. Harlow: Pearson.

7. M. Kämpf \& H. Montenegro. (1997). On the performance of capillary barriers as landfill cover. Hydrology and Earth Systems Sciences 4, 925-929.

8. M. Aubertin, E. Cifuentes, S. A. Apithy, B. Bussière, J. Molson, R. P. Chapuis. (2009). Analyses of water diversion along inclined covers with capillary barrier effects. Can. Geotech. J. 46, 1146-1164. doi:10.1139/T09-050

9. F.R. Harnas, H. Rahardjo, E. C. Leong, J. Y. Wang. (2014). Experimental study on dual capilary barrier using recycled asphalt pavement materials. Can. Geotech. J. 51, 1165-1177. doi: dx.doi.org/10.1139/cgj-2013-0432

10. M.C. Barros. (2005). Avaliação de um resíduo da construção civil beneficiado como material 
alternativo para sistema de cobertura. 96 p. Dissertation (Civil Engineering Master)-Instituto Alberto Luiz Coimbra de Pós-Graduação e Pesquisa de Engenharia, Universidade Federal do Rio de Janeiro, Rio de Janeiro.

11. M. Kämpf, T. Holfelder, H. Montenegro. (2003). Indentificacion and parameterization of flow processes in artificial capillary barriers. Water Resources Research 39:10, 1-9. doi: 10.1029/2002WR001860

12. J. Almeida. (2011). Estudo do comportamento de barreira capilar em aterros de resíduos. $152 \mathrm{p}$. Dissertation (Civil Engineering Master)-Instituto Alberto Luiz Coimbra de Pós-Graduação e Pesquisa de Engenharia, Universidade Federal do Rio de Janeiro, Rio de Janeiro.

13. R. L. S. Izzo, C. F. Mahler, L. Rose. (2013). Barreira capilar construída com resíduo pré-tratado mecânica e biologicamente. Eng Sanit e Ambient 18:4, 303-312.

14. T. L. T. Zhan, H. Li, G. W. Jia, Y. M Chen, D. G. Fredlund. (2014). Physical and numerical study of lateral diversion by three-layer inclined capillary barrier covers under humid climatic conditions. Can. Geotech. J. 51, 1438-1448. doi: dx.doi.org/10.1139/cgj-2013-0449

15. C.W. Ng, J. Liu, R. Chen, J. Xu. (2015). Physical and numerical modeling of an inclined three-layer (silt/gravelly sand/clay) capillary barrier cover system under extreme rainfall. Waste Management. doi: http://dx.doi.org/10.1016/j.wasman.2014.12.013

16. ABNT. (2017). NBR 16605: Cimento Portland e outros materiais em pó - Determinação da massa específica. Rio de Janeiro.

17. ABNT. (2016). NBR 7181: Solo - Análise granulométrica. Rio de Janeiro.

18. ABNT. (2016). NBR 7182: Solo - Ensaio de compactação. Rio de Janeiro.

19. ABNT. (2000). NBR 14545: Solo - Determinação do coeficiente de permeabilidade de solos argilosos a carga variável. Rio de Janeiro.

20. ABNT. (1995). NBR 13292: Determinação do coeficiente de solos granulares à carga constante. Rio de Janeiro.

21. L. F. S. Villar. (2002). Estudo do adensamento e ressecamento de resíduos de mineração $e$ processamento de bauxita. 461 p. Thesis (Civil Engineering Doctor degree)-Programa de PósGraduação em Engenharia Civil, PUC-Rio, Rio de Janeiro.

22. J. C. O. Bizarreta. (2009). Avaliação do potencial de uso de um resíduo da indústria de papel em sistemas de barreiras capilares. 108 p. Dissertation (Civil Engineering Master)-Departamento de Engenharia Civil, PUC-Rio, Rio de Janeiro.

23. ABNT. (2016). NBR 6457: Amostras de solo Preparação para ensaios de compactação e ensaios de caracterização. Rio de Janeiro.
24. SIMEPAR - Sistema Meteorológico Do Paraná (2019). Dados pluviométricos de estação em Foz do Iguaçu no intervalo de 31/12/1997 a 31/12/2018.

25. J. L. B. Moreira. (2002). Estudo da Distribuição espacial das Chuvas em Belo Horizonte e em seu entorno. Dissertation (Master). UFMG, Belo Horizonte.

26. M.D. Costa, M. O. H. Mariano, L. B. Araujo, J. F. T. Jucá. (2018). Estudos laboratoriais para avalização do desempenho de camadas de cobertura de aterros sanitários em relação à redução de emissões de gases e infiltrações. Eng Sanit Ambient 23:1, 77-90. doi: 10.1590/S1413-41522018160393

27. F. J. Maciel \& J. F. T. Jucá. (2011). Evaluation of landfill gas production and emissions in a MSW large-scale experimental cell in Brazil. Waste Management 31, 966-977. doi: 10.1016/j.wasman.2011.01.030

28. B. M. Das \& K. Sobhan. (2017). Fundamentos de Engenharia Geotécnica. 8. ed. São Paulo: Cengage Learning.

29. M. V. Khire, H. Benson, P. J. Bosscher. (2000). Capillary barriers: design variables and water balance. Journal of Geotechnical and Geoenvironmental Engineering 126:8, 695-708.

30. M. A. B. Silva Junior. (2010). Avaliação da potencialidade dos RCD's visando sua aplicação em cobertura final de aterros. Undergraduate thesis (Civil Engineering) - Escola Politécnica de Pernambuco, UFPE.

31. H. Krisdani, H. Rahardjo, E. C. Leong. (2005). Behaviour of capillary barrier system constructed using residual soil. Waste Containment and Remediation. 1-15.

32. V. L. Hauser. (2009). Evapotranspiration Covers for Landfills and Waste Sites. Boca Raton: Taylor \& Francis Group.

33. K. T. Silva. (2016). Projeto de um aterro sanitário de pequeno porte. 81 p. Design (Civil Engineering) Escola Politécnica, UFRJ.

34. R. F. Oliveira \& R. M. Q. L. Braga. (2017). Sistema de cobertura final de um aterro sanitário para a RMB de Belém-PA com emprego de resíduos da construção civil. Revista Gestão e Sustentabilidade Ambiental, Florianópolis 6:3, 573-596. doi: 10.19177/rgsa.v6e32017573-596

35. X. Qian, R. M. Koerner, D. H. Gray. (2002). Geotechnical Aspects of Landfill Design and Construction. New Jersey: Prentice Hall. 